\title{
Media - teatr/spektakl ${ }^{*}$
}

ABSTRACT. Gwóźdź Andrzej, Media - teatr/spektakl [Media - theatre/spectacle]. „Przestrzenie Teorii" 3/4, Poznań 2004, Adam Mickiewicz University Press, pp. 175-189. ISBN 83-232-1454-9. ISSN 1644-6763.

Considering the nature of the relation medium - form the author proposed an insight into two models of relationships between the cinema and the theatre: the first one including the decade of 1925-1935 and the contemporary one. However, the author is not concerned with how the theatre takes advantage of the achievements of the cinema, but he wishes to show the intermedial relationships which join the stage with the screen at the level of the medium - as a vision machine incorporated into a wide system of culture. And this is connected not only with techniques of forming the presented worlds, but first of all with calculating newer and newer environments for technology of the technically mediated seeing. Thus, if intermedia character was formerly expressed in the exchange of forms between the media (film in the theatre/spectacle in film), then the contemporary spaces of the borderline (represented, let's say, through Peter Greenaway's installations) concern tensions between the materiality of the world, medial character of cinema images and mobility of the spectator. Theatre becomes here an element of film culture, and film intervenes in the stage creating spectacles of medial interfaces.

To nie tyle $\mathrm{z}$ własną formą, ile raczej $\mathrm{z}$ medium musiał uporać się film od zarania swego istnienia. Bo form (medialnych), w których przyszło mu się wyrażać, nie brakowało. Ale samo medium komunikowania pozostaje amorficznym, luźno ze sobą powiązanym zbiorem elementów, dopóki nie wypełni się ich mocnym sprzężeniem (a więc gęstą siecią wzajemnych relacji), a to znaczy - formą właśnie [Luhmann 1997, 165-214].

Sensu opozycji medium-forma przydaje różnica: nie istnieje medium, które byłoby tożsame $\mathrm{z}$ jedną tylko formą, bo wtedy zostałoby $\mathrm{z}$ nią zrównane, w konsekwencji zatem wymazane jako medium. Ale też jedynie forma jest władna określić, co stanowi dla niej medium. Światło nie wyczerpuje zatem wszystkich możliwości fotografii, film nie wyczerpuje wszystkich możliwości ruchomego wizerunku, a wszystkie one nie wyczerpują wszystkich możliwości kina jako „medium notacji” [Luhmann $1986,8]$ powieści, dramatu czy opery (z czego doskonale zdawali sobie sprawę chociażby psychoanalitycy kina). I odwrotnie: ta sama forma

- Prezentowany tekst jest wersją referatu wygłoszonego na konferencji „Teatr - media - kultura", zorganizowanej z okazji Jubileuszu 50-lecia pracy naukowej prof. dr hab. Eleonory Udalskiej przez Zakład Wiedzy o Teatrze Instytutu Nauk o Kulturze Uniwersytetu Śląskiego w dn. 16-17 kwietnia 2004 roku w Ustroniu. W poszerzonej wersji ukaże się w pracy A. Gwóźdź, Technologia widzenia, czyli media w poszukiwaniu autora: Wim Wenders, Kraków 2004. 
może się wyrażać w różnych mediach, bo ich możliwości kombinatoryczne są ogromne, tworząc ciąg alternacyjny forma-medium oparty na szeregu: światło/fotografia/film/kino/telewizja/wideo/CD-ROM/DVD/Sieć (jeśli pozostać jedynie w obrębie mediów reprodukcji technicznej). Wtedy światło nie będzie już dłużej postrzegane jako środek rejestracji tylko (medium transmisji), ale ogarnie sobą kolejne szczeble medialności, samo w sobie osiągając status medium komunikowania lpor. Wollen 1982, 197].

Ale to forma (filmu) właśnie stanowi medium dla szerszej formacji ruchomych obrazów (na przykład animacji typu malarskiego), te zaś przyjmują u obserwatora status medium chociażby dla dwuwymiarowych wizerunków itd. To ona "dopiero tworzy medium, w którym się wyraża. Stanowi wtedy "medium wyższego stopnia", drugiego porządku, umożliwiając ze swej strony medialne wykorzystanie różnicy między medium a formą jako medium komunikowania właśnie" [Luhmann 1986, 8].

Co więcej, to dzięki rozpoznaniu różnicy między medium (otwartym na formy) a formą (koordynującą elementy medium) film może funkcjonować jako środek komunikowania, bo dzięki niej zostaje ukonstytuowany jako medium właśnie. Jeśli więc „normalnie” postrzegamy ruchome obrazy jako różniące się od potoku życia (różnica medium sztuki - medium „rzeczywistości”, określająca intencję przekazu sensów od jej braku), albo - z drugiej strony - od obrazów nieruchomych (różnica: medium - inne medium), to istotą „kina” (i każdej sztuki) pozostaje to, że wymusza koncentrację na innej fundamentalnej różnicy: tej, jaka zachodzi między medium a formą. Ale fortunne rozpoznanie owej różnicy wymaga każdorazowo ustanowienia jej na nowo w obrębie określonego systemu przedstawień - w tym przypadku „kina” właśnie ${ }^{1}$.

W sensie instrumentalnym, rzeczowym film to były od początku przecież obrazy świetlne zapisane na taśmie filmowej wprowadzanej w ruch (ruchome wizerunki) oraz aparaty służące ich projekcji. A po stronie odbiorcy - poparte doświadczeniem (kompetencją) oczekiwanie, iż możliwy jest dwuwymiarowy ruch wizerunku w czasoprzestrzeni innej niż miejsce projekcji, a więc przyzwolenie na „oddalone wystawienie”

1 Proponowane rozumienie medium nie ogranicza się zatem do materialności komunikowania, technik produkcji i rozpowszechniania, organizacji wraz $z$ ich uwarunkowaniami społeczno-ekonomiczno-prawnymi, które sankcjonują symbolicznie związek między nadawcą a odbiorcą. W przyjętej perspektywie systemowej pojęcie medium - według Luhmanna i w nawiązaniu do teorii Talcotta Parsonsa: "symbolicznie zgeneralizowane medium komunikowania" [Luhmann 1986, 11] - odnosi się do rozmaitych symbolicznych środków wymiany informacyjnej, w przypadku sztuki podległych obserwacji drugiego stopnia (obserwowanie obserwacji innych), umożliwiającej obserwowanie procesorowania form na rzecz mediów. 
[Carroll 1996, 70]. To odróżniało i nadal odróżnia film od wcześniejszych widowisk projekcyjnych, bo jego istota - w przeciwieństwie do obrazów nieruchomych, przezroczy, kamery obskury, panoram czy dioram - tkwi w możliwościach zapośredniczonej technicznie iluzji ruchu wytwarzanego za pomocą znaku-szablonu (projekcja naświetlonej taśmy, emisja taśmy wideo, odczyt DVD albo programu komputerowego), podlegającego zasadom „przekazu nieartystycznego" [patrz Carroll 1996, 67]2. I to „naraża” film na nieustanne funkcjonowanie w przestrzeni pomiędzy różnymi przekaźnikami czyniąc go zarazem w sposób naturalny multi- bądź intermedialną formą medium, skoro projekcja bezkonfliktowo wpisuje się w ramy różnych mediów i przyjąć ją mogą najrozmaitsze sztuki i nie-sztuki.

Dla filmu zatem - ale także dla innych mediów przedstawiających medium „wyjściowym”, „prymarnym” albo „medium postrzegania” (jak je nazywa Luhmann w przeciwienstwie do medium komunikowania, na przykład telewizji czy kina) pozostaje światło, nad którym - jako medium drugiego stopnia - nadbudowana zostaje forma filmu. To światło jest owym medium postrzegania (ale także notacji), dzięki któremu ponad siedemdziesiąt lat temu projekcja kinematograficzna połączyła w jedno to, co kultura zdołała wcześniej rozdzielić na oralność, piśmienność i obrazowość, a mianowicie słowo mówione, pisane i znaki ikoniczne w pisanie za pomocą światła. Bo niezależnie od „zawartości” filmu to przecież ślad światła pozwala unaocznić się obrazowi pisma i mowy w filmie, a „podkreślenie roli światła, jego wartość poglądowa bierze się głównie z warunkowanego przez nie postrzegania". Oznacza to, iż w świetle zawiera się „porządek, który sens uzyskuje tylko przez sprowadzenie do odpowiedniego przedmiotu" [Heider 1926, 152, 135]. Irytacja oka nową funkcją światła sprawi, iż stanie się ono prawdziwym wyzwaniem dla wzroku, który przez cały XX wiek będzie się musiał borykać z tym problemem. To właśnie musiał mieć na myśli Marshall McLuhan, kiedy formułował swą wiekopomną teze na temat przekazu jako przekaźnika motywując ją uwagą, iż "treścią (albo inaczej "zawartością") danego przekaźnika jest inny przekaźnik", co w przypadku mediów operujących wizerunkami oznacza, iż „światło jest czystą informacją, niejako przekaźnikiem nie zawierającym żadnego przekazu”, a „[..] zawartością filmu jest powieść, dramat albo opera" [McLuhan 1975, 46, $45,56]$.

2 „Przedstawienie teatralne - pisze Carroll - generowane jest przez interpretację, która stanowi typ, podczas gdy przedstawienie filmowe - przez szablon, który jest znakiem" (Caroll 1996, 70), co oczywiście nie zmienia faktu, iż pewne typy aktywności projekcyjnej (zwłaszcza wczesnego kina, jak również w obrębie różnych awangard filmowych) zbliżały je mimo wszystko do przedstawienia teatralnego, definiowanego przez Carrolla jako to, które „tworzone jest przez interpretację" (ibidem, 68). 
Intermedialność jawi się $\mathrm{w}$ takiej perspektywie jako proces fuzji form - przyłączania form(y) jednego medium „po stronie” form(y) innego medium, co pociąga za sobą rozmaite figuracje samozwrotności mediów; albo dotyczy procesu transpozycji form(y) w obrębie tego samego medium (a zatem odnosi się do transferu wewnątrzmedialnego). W pierwszym przypadku figuracje intermedialne związane są z procesem wyłaniania się form jednego medium $w$ obrębie form innego (na przykład wykorzystanie kompozycji obrazu malarskiego w komponowaniu sceny filmowej tak, iż między malarstwem a filmem dochodzi do fuzji formy malarskiej i filmowej); w drugim zaś obejmują procedury wymiany jednych form na inne w taki sposób, iż kontrahentami tej wymiany stają się pierwotne media tych form (na przykład „ufilmowienie” malarstwa w awangardzie filmowej lat dwudziestych, a także procesy transformacji intertekstualności w intermedialność). W obydwu przypadkach intermedialność ustanawia różnice między formami a mediami, może więc być postrzegana jako proces sankcjonowania zróżnicowania mediów [por. Paech 1997, 336-337 oraz Paech 1998]. Ale też medium samo w sobie nie jest dostępne poznawczo inaczej, jak tylko dzięki formom, które umożliwia, stanowi zatem także konstrukt obserwacyjny, który powstaje w wyniku obserwowania procesorowania form, jakie $\mathrm{z}$ siebie wyłania.

Bo też od swoich narodzin kino borykało się $\mathrm{z}$ problemem swojego miejsca $w$ pejzażu kultury i sztuki-niesztuki. Jeżeli jednak $w$ miarę szybko zdołało ustabilizować się jako technika projekcyjna ruchomego wizerunku ( $\mathrm{z}$ powodzeniem wpisując się $\mathrm{w}$ tradycję demonstracji projekcyjnych), to inne cechy medialności pozostawały długo niepewne. „Nie chodziło $w$ tym przypadku o jego możliwości techniczne, nie wystarczała techniczna gotowość kamery, projektora czy kliszy z obrazami. Co więcej, one już tam były, mniej lub bardziej gotowe, w mniejszym lub większym stopniu wynalezione znacznie wcześniej przed formalnym wynalazkiem kina, na pięćdziesiąt lat przed Edisonem i braćmi Lumière. Istniała konieczność stworzenia, uformowania czegoś innego - maszyny filmowej, niekoniecznie będącej kamerą, filmem, projektorem, nie stanowiącej jedynie kombinacji przyrządów, aparatów, technik. A która wszak pozostaje maszyną: dyspozytywem spajającym ze sobą różne układy: technologiczne, ekonomiczne, ideologiczne. Niezbędny był [...] porządek nadający aparatowi i technikom status społeczny i funkcję" [Comolli 2001, 448].

Toteż pierwszy komercyjny pokaz w berlińskim varieté Wintergarten (Ogród Zimowy) bioskopu braci Skladanowskich 1 listopada 1895 roku, a potem grudniowe popołudnie w Salonie Indyjskim paryskiego Grand Café, stanowiły zwieńczenie rozwoju archaicznych technik (czasem także sztuk) projekcyjnych (latarnia magiczna, kamera obskura, przezrocza) 
i scenicznych inscenizacji symulacyjnych (panorama, diorama, „obrazy mgielne”), a zarazem kulminację efektu widzialności związanego z jazdą koleją oraz praktykami inscenizacyjnymi handlu, wypełniającymi przestrzeń powstających równolegle $\mathrm{z}$ kinem jako spektaklem wielkich domów towarowych. Zwieńczenie, bo wiele $\mathrm{z}$ dawnych prekinowych maszyn widzenia istniało nadal, a niektóre $\mathrm{z}$ nich - chociażby latarnia magiczna - istnieją po dziś dzień, chociażby w zelektryfikowanej postaci projektora do przezroczy.

To wówczas, w listopadzie i grudniu 1895 roku, bracia Skladanowscy w Berlinie, a Lumière w Paryźu dali początek nie tylko nowemu widzeniu, ale zainicjowali także „nowy rynek, nową gałąź przemysłu, produkującą miast materii światło" [Virilio 1984, 2], oferowane odtąd nabywcom w zamian za wykupienie prawa do uczestnictwa w spektaklu światła i cienia. Dwa niezbywalne dla spektakularyzacji przedstawień ekranowych (a więc kina jako spektaklu) filary stanowią zatem, $\mathrm{z}$ jednej strony, samo miejsce handlu $\mathrm{z}$ niematerialnymi przedstawieniami, $\mathrm{z}$ drugiej - sposoby inscenizacji projekcji jako strategie demonstrowania filmu.

W pierwszych latach istnienia kina stawką było więc głównie to, jak ustabilizować się jako nowa maszyna widzenia, co wiązało się zarówno $\mathrm{z}$ technikami tworzenia światów przedstawionych, jak i koniecznością poszukiwania adekwatnego środowiska projekcji, ale zarazem i kalkulowania coraz to nowych możliwości jej spektakularyzacji. Czy kino miało pójść na przykład tropem kinetoskopu Edisona, będącego przedsięwzięciem obliczonym na prywatny ogląd filmu (i z założenia stanowiącym optyczny „dodatek” do fonografu), czy też stać się spadkobiercą panoram $\mathrm{z}$ ich ideologią widzialności opartą na efektach przestrzennych i zbiorowym oglądzie? Czy tworzyć światy zdominowane przez formy sceny teatralnej albo mobilizować nowe widzenie, którego rudymenty podpowiadała już czasami fotografia?

Bo na horyzoncie dokładnie w tym samym 1895 roku pojawił się przecież wielki konkurent kina - aparat rentgenowski, z którym do roku 1898 rywalizowało ono nie tylko na jarmarkach, ale i na scenie teatru iluzji „Robert-Houdin”, po czym zaczęło ustępować popularności promieni X [patrz Cywjan 2001, 214]. Ta równoległość kina i rentgena sprawiała, iż „naruszona została kulturowo-semiotyczna równowaga pomiędzy przedstawieniem i jego przedmiotem", że dokonywał się swego rodzaju "striptiz" semiotyczny" polegający na tym, iż przekroczono „normę podobieństwa życiowego, przyjętą dla przedstawienia w końcu XIX wieku", o którym sądzono, że doprowadzi do syntezy kina i aparatu prześwietlającego [Cywjan 2001, 214-215]. W każdym razie przełamywanie tabu niewidzialnego od chwili wynalezienia mikroskopu, mikrofo- 
tografii i mikrozdjęć filmowych osiągnęło swe tymczasowe apogeum, a kinematograf stał się „nowym rozdziałem w historii podglądactwa” [Cywjan 2001, 220].

Równocześnie dobrze się miały tradycyjne technologie widzenia oparte na projekcjach, $\mathrm{z}$ jednej, i dawne teatralne oraz parateatralne techniki przedstawiania świata, z drugiej strony, które niezwykle silnie ingerowały w syndrom projekcji, stanowiąc zarazem wczesne świadectwo intermedialności X muzy.

Ale to właśnie w projekcji (której nie wymagał Edisonowski kinetoskop) zawiera się technokulturowy sens kina jako medium, skoro zespala ona aparat $\mathrm{z}$ dyspozytywem, technikę $\mathrm{z}$ odbiorcą, $\mathrm{z}$ całą mocą uświadamiając zarazem, że żadne pojedyncze medium nie stanowi esencji kina. I że film - nawet jeśli sam w sobie stanowi już medium światła jako przekaźnika światów ekranowych (utwierdzając swe genealogiczne powinowactwo z wcześniejszymi mediami świetlnymi) - musi „posiąść” wiele innych mediów, bo to dzięki nim dopiero staje się określoną technologią widzenia. A liczne spośród nich czekają przecież jeszcze na swe odkrycie [por. Musser 1984]. Dlatego od samego początku film zdany był na funkcjonowanie między różnymi mediami, w rezultacie czego ksztaltowanie się instytucji kina dokonywało się nie tylko w przestrzeni pomiędzy rozmaitymi instytucjami społecznymi, kulturalnymi i naukowymi, ale przede wszystkim na styku odmiennie ufundowanych medialnie form prezentacyjnych filmu.

Pamiętać bowiem trzeba o tym, iż inicjacja nowego medium dokonywała się zasadniczo w paradygmacie popularnej kultury teatralnej (co niekoniecznie oznacza - niskiej), w obrębie wyznaczanym przez rozrywkowy teatr bulwarowy (variétés) i jego bardziej plebejską formę - ludowe variétés, w Niemczech zwane tingel-tanglem [por. Brewster, Jacobs 1997 oraz Garncarz 1998]. Projekcja filmowa rozpoczyna więc swój historyczny pochód jako składnik programowy szerszej struktury przedstawieniowej - wielotworzywowego pokazu scenicznego, w którym film nie był medium ani najważniejszym, ani niekoniecznie najbardziej oklaskiwanym, i który wyróżniał się jako wielomedialny program (swego rodzaju serial), a nie dzieło. Tego rodzaju "multimedialna partytura”, złożona z kombinacji najróżnorodniejszych „numerów” scenicznych i parascenicznych variétés decydować będzie o jednej $\mathrm{z}$ najwcześniejszych form medialnych $\mathrm{X}$ muzy, a jej żywotność przetrwa rozliczne zakręty historii kina.

To bowiem, czego oczekiwało ówczesne ,ja spektatorialne" [Chyła $1987,18]$, to nie byl pojedynczy film oglądany w skupieniu ani nawet zestaw filmów połączonych ze względu na jednoczące je kryterium, ale różnorodność oraz bogactwo złożonego programu, zawierającego między 
innymi także i film. Tym, między innymi, tłumaczą niektórzy klęskę „bioskopu” braci Emila i Maxa Skladanowskich w berlińskim Ogrodzie Zimowym w listopadzie 1895 roku: filmy niemieckich prekursorów kina reprodukowały w istocie „numery” czynnej nieopodal „żywej” sceny, respektując nawet układ czasowy piętnastominutowych programów. W rezultacie widzowie - choć nie pozbawieni szoku mentalnego i wynikającej stąd fascynacji odmiennością rzeczywistości ekranu i sceny współuczestniczyli nadal w ,innym takim samym” widowisku scenicznym, obcując z odmiennymi medialnie formami, które już za chwilę i tak jawiły im się bez pośrednictwa maszyny [por. Hickethier 1996, 362-368].

Spektatorializacja kina miała jednak także swój mniej oficjalny, podskórny niejako nurt, dotykający głównie samego aparatu kina jako maszyny projekcyjnej, a związany na ogół z „konsumpcyjnym” modelem odbioru filmu - jako dodatku do usług gastronomicznych. Oto w dość typowych na przełomie wieków salach projekcyjnych $\mathrm{z}$ wyszynkiem - lub po prostu restauracjach - widzowie zasiadali przed i za przezroczystym ekranem, a ponieważ aparat projekcyjny ustawiano za ekranem, ci mieli go nieustannie w polu swego widzenia (i słyszenia), tak jak dzisiaj obrazowi telewizyjnemu towarzyszy obecność maszyny emisyjnej, jaką jest telewizor, rozmaicie inscenizowany przez kolejne mody designu. Ale także w licznych jeszcze na początku XX wieku kinematografach objazdowych demonstrowanie sprzętu kinematograficznego wraz z generatorem prądu stanowiło nie lada atrakcję, a wędrowni demonstratorzy nierzadko objaśniali widzom zarówno zasady produkcji filmów, jak i ich projekcji.

Być może należałoby mówić wręcz o wykształceniu się jednej z praktyk projekcyjnych, polegającej głównie na oglądaniu „maszyn widzialności”, a nie samych filmów, zainteresowaniu technologią projekcji przede wszystkim, a nie wydarzeniami na ekranie: to pracujący projektor wraz z obsługującym go operatorem stanowil atrakcję wizualną, ze względu na którą szło się do kina [por. Zielinski 1989, 64]. Rzecz dość niezwykła, zważywszy podstawowe teorematy odbioru filmu, wśród których „wrażenie realności" należało zawsze do konstytutywnych w procesie percepcji. Pamiętać jednak musimy o tym, iż inauguracja kina jako medium dokonywała się nie tylko i raczej nie przede wszystkim w paradygmacie teatropodobnym, ale w dużym stopniu zdominowana była przez awans technologiczny kultury materialnej przełomu XIX i XX wieku. A jako maszyna medialna lokowalo się ono przecież - obok aparatu rentgenowskiego, podobnie jak wcześniej fonografu - w awangardzie osiągnięć technicznych swojego czasu, stanowiąc istotny element strategii „kina atrakcji" [por. Gunning 1990].

181 Media-teatr/spektak| 
Choć przecież w takim wypadku o odbiorze filmu w ogóle nie może być mowy. Kino jako miejsce przedstawień zostaje wyłączone $\mathrm{z}$ paradygmatu estetycznego i włączone do paradygmatu scjentystycznego - to maszyna widzenia produkująca światło i ruch awansuje do rangi przedmiotu demonstracji, a nie obrazy, które rzutuje na ekran. Tutaj porządek rzeczy dominuje nad porządkiem reprezentacji, sprawiając, że efekt widzialności awansuje projektor do przedmiotu spektaklu.

Nie dziwi więc, iż kino zmuszone było głównie poszukiwać swojej tożsamości jako „forma-w-medium” [Luhmann 1997, 171], zabezpieczać ślad przekaźnika raczej niż system znakowy, a z drugiej strony - w perspektywie instrumentarium technicznego - jako maszyna emocji multimedialnych raczej niż sztuka. Choć zastanawia, z jaką determinacją samą projekcję starano się awansować do rangi dzieła sztuki. Bo oto już najwcześniejsza praktyka projekcji filmowych (obsługiwanie mechanizmu projektora za pomocą poruszanej ręcznie korbki) sprzyjała powstawaniu określonych stylów projekcji: filmy „nudne” sztucznie przyspieszano, a sceny ekscytujące zwalniano. Czy zatem $\mathrm{w}$ odniesieniu do projekcji można mówić o jej walorze artystycznym albo - ostrożniej o tym, że stanowiła ona element nieobojętny $z$ estetycznego punktu widzenia? Wiadomo chociażby, iż wśród kinooperatorów kina niemego byli tacy, którzy cieszyli się szczególnym uznaniem, i to na projekcje z ich udziałem chodziło się do kina. Zapewne ma więc rację Noël Carroll, kiedy twierdzi, iż „interpretacje i występy, którymi artyści ci przyczyniają się do powstania określonego typu ruchomego obrazu, zostają włączone do produktu finalnego jako elementy konstytuujące ten typ ruchomego wizerunku" [Carroll 1996, 70].

W każdym razie w ciągu całej swej historii kino poszukuje własnej tożsamości bardziej jako medium aniżeli forma (dzieła sztuki). Szczególnie w okresie przesileń technologicznych - w dekadzie 1925-1935, 19501960 i współcześnie - musi ono na nowo przemyśleć, by nie rzec: wymyślić swój status jako środek przekazu. A to oznacza: odnaleźć siebie w nowym medium (nowych mediach), dokonać wyboru i rekombinacji w obrębie możliwości oferowanych przez napięcia wynikające $\mathrm{z}$ układu media-dla-form.

Wówczas, w latach trzydziestych, przychodziło mu to czynić w sytuacji, w której punktem odniesienia intermedialnego manewru filmu przestają być „stare" sztuki (literatura, teatr), bo na horyzoncie pojawiają się radio i telewizja - owa "krewniaczka samochodu i samolotu" [Arnheim 1961, 149] - a więc przekaźniki przede wszystkim, a nie sztuki. Ale też cała kultura tego okresu staje się $\mathrm{z}$ wolna kulturą zapośredniczonych strategii i funkcji, ujawnionych chociażby $w$ kulminacji naczelnej idei schyłkowego wieku XIX, jaką było rozerwanie ciągłości doświadczenia na 
fragmenty i serie następstw oraz ponowne ich złożenie w nową jakość (w kinie za pomocą montażu). Jest jak owa kostka bulionowa firmy Maggi (wyprodukowana dokładnie w roku narodzin kina), dokumentująca przejście od produktu naturalnego do prefabrykatu powstałego w sposób przemysłowy, niwecząca związek między przyczyną a skutkiem, a tym samym zaświadczająca utratę zmysłowo postrzeganej rzeczywistości. Krótko mówiąc - sankcjonująca rozdział składników od gotowego produktu, pociągający za sobą dyslokację i rozsunięcie czasowe $\mathrm{w}$ imię racjonalizacji produktu końcowego, a w konsekwencji odseparowanie sensu od bezpośredniego doświadczenia.

Proces ten obejmuje wiele innych połaci kultury. Chociażby rozwój aglomeracji miejskich, które w dekadzie 1925-1935 zdołały już okrzepnąć jako wielowarstwowe układy niepoddające się jednolitej, kompleksowej logice kontemplacji, bo pozbawiające odbiorcę możliwości bezpośredniego doświadczenia, wymagające tworzenia konstrukcji sensów z rozczłonkowanych mikrostruktur rzutu oka. Ale w sukurs przyszły nowoczesne środki lokomocji, pozwalające na przeżywanie miasta jako swego rodzaju nowej, bo mobilnej (choć dlatego także skrajnie zatomizowanej) widzialności. Miasto przeżywa się teraz głównie jako przestrzeń percepcyjną - to ona zawiera w sobie podstawowy scenariusz lektury znaczeń - a doświadczenie wizualne decyduje o stylu życia miejskiego: lazikującego flâneura wypiera pospieszny, znerwicowany podmiot dryfujący pomiędzy różnymi ofertami wizualnymi ${ }^{3}$. Dostrzec to można także w sposobach inscenizowania towarów w nowoczesnych domach handlowych, coraz bardziej pozbawiających je związków $\mathrm{z}$ własnym pochodzeniem i procesem produkcyjnym, coraz powszechniej wyposażających w różnorodne konteksty otwierające się na różne scenariusze konsumpcyjne klienta, oparte zwykle na montażu atrakcji (pośród których ważne miejsce zajmuje dziś kino).

W drugiej połowie lat dwudziestych wszystkie te procesy osiągnęły stan krytyczny, a kompleksowość doświadczeń wizualnych wzrosła na tyle, iż film musiał być postrzegany jako właściwe medium „władzy wzroku nowoczesności" [Jay 1999, 78]. W każdym razie ekran kinowy stanowił środek kumulujący w sobie wielość owych cywilizacyjnych doświadczeń, ale zarazem kompensujący utratę spójności, wiążący na powrót wszystkie postradane po drodze nitki sensów. Dlatego film, swobodnie rezonując $\mathrm{w}$ przestrzeni kultury i wielości intermedialnych dyskursów, poszukiwał dla siebie miejsca w obrębie różnych praktyk ekra-

${ }^{3}$ Nieprzypadkowo zatem taka moda przypada w owym czasie na tzw. filmy uliczne, dające wyraz tęsknocie za stymulacją wzrokową, a Berlin. Symfonia wielkiego miasta Waltera Ruttmanna (Niemcy 1927) staje się w tym względzie filmem prototypowym [por. Hoormann 2003, 270-286]. 
nowych. Z jednej strony umacniał się jako „proteza ontologiczna” łącząca ruchome obrazy ze światem pozafilmowym, z drugiej zaś aktywnie pracował na rzecz własnej „logiki tego co widzialne”, niekoniecznie utwierdzającej jego status w zgodzie z tą pierwszą [Elsaesser 2002, 21, 35].

Z perspektywy historycznofilmowej oznacza to, iż miejsce filmu nie tyle tkwi w poszczególnych filmach, ile raczej między nimi, a więc to nie archiwum filmowe (stojące na straży linearności porządku przyczynowo-skutkowego i teleologii) wyznacza perspektywę oglądu jego historii, ale wielość poetyk kultury i praktyk multimedialnych, pozwalających odczytywać sposoby pracy kina na rzecz jego własnej genealogii (niekoniecznie archeologii), jego miejsca pośród innych fenomenów kultury. Bo też nie o film jako tekst czy artefakt tu głównie chodzi, lecz o medium rozpostarte między różnymi aparatami (audio)wizualnymi, różnymi formami dystrybucji i technologiami nośników.

Można bowiem zaryzykować tezę, iż w swych technokulturowych przemianach - zmierzania od rejestracji fotograficznej do kreowania światów wirtualnych - media audiowizualne ulegają coraz bardziej swego rodzaju teatralizacji, wypełniając się nieuchronnie teatralikami. Choć przecież to już inne teatraliki niż te $\mathrm{z}$ czasów braci Skladanowskich. Mówiąc krótko: robią ze świata teatr, tzn. mamią nas efektem bycia w świecie ekranu, podczas gdy w istocie pozostają w przestrzeni teatru.

A teatr jest zawsze totalnie live, bo ontologia czasu rzeczywistego pokrywa się tu $\mathrm{w}$ pełni $\mathrm{z}$ kolportowanym przezeń efektem tu i teraz. A to znaczy, iż „na żywo" stanowi coś więcej niż tylko poczucie wspólnoty odbiorców - to pewien ideologiczny efekt bycia razem $w$ jednej chwili w jednym miejscu. Czyż nie dlatego właśnie mówimy o „teatrze”, a nie o „kinie wojny”, choć związki łączące X muzę z polem bitwy są więcej niż udokumentowane (najciekawiej pisal o tym Paul Virilio)? I dlatego ten sam Virilio właśnie o kinie pisze jako o „maszynie widzenia”, choć to przecież teatr jest maszyną sensu stricto.

Takim kinem w naturze była Greenawayowska inscenizacja The Physical Self $\mathrm{w}$ rotterdamskim Boymans-van Beuningen Museum (1991), wystawiająca ludzkie fizjonomie na pokaz w oszklonych gablotach. Żywe ciała jako obrazy w iluzorycznej osnowie kina do oglądania w „teatralnych" witrynach: między materialnością sceny teatralnej, medialnością kinematograficznych obrazów a mobilnością widza. Nie jest zatem rzeczą przypadku, iż to postmodernistyczny Peter Greenaway właśnie uczynił z Szekspirowskiej Burzy partyturę wysublimowanych fantazji cyfrowych w filmie Ksiegi Prospera (Francja-Włochy-Holandia- 
Wlk. Brytania-Japonia 1991) - filmowy teatr na styku kultury piśmienności, teatralizacji i ruchomego obrazu. Co więcej, na bazie filmowej lektury Szekspirowskiego dramatu "wyekstrahowal" zeń choreograficzny "link" - ukryty pod tamtym filmem niczym palimpsest Spacer przez bibliotekę Prospera (A Walk through Prospero's Library, 1991, tv).

Wypada więc spojrzeć na ów interfejs między rzeczywistością sceniczną a innymi rzeczywistościami komunikacyjnymi, wśród których prym mimo wszystko wiedzie dziś kultura ruchomych obrazów, od ponad stu lat matrycująca nasze doznawanie świata i wiedzę o nim w stopniu niemającym sobie równych $\mathrm{w}$ dziejach cywilizacji. Bo nie ulega przecież wątpliwości, iż ów dyskurs na temat przenikania sceny i ekranu, tak odmienny dziś od wszystkiego, co dawniej określało styk teatru i kina, najlepiej reprezentuje twórczość Petera Greenawaya.

Jeśli przyjrzeć się tej formacji kina, którą skłonny jestem określać mianem kina „nowych widzialności” (patrz Gwóźdź 2003, 160-196) łatwo dostrzec, jak silne są to związki. „Telewizyjne” filmy Petera Greenawaya na przykład, zwłaszcza A TV Dante - Cantos 1-8 (Wlk. Brytania 1989), lansują nawet coś w rodzaju filmowej rozmowy „na stronie” - swoiste tabu narracji filmowej zostaje przełamane. A Dzieciątko $z$ Mâcon (Wlk. Brytania-Francja-Niemcy- Belgia-Holandia 1993) i M jak Mozart (Wlk. Brytania 1991) to przecież nic innego, jak opery filmowe, z całym sztafażem interakcji między widownią a sceną włącznie. Ale przecież już $\mathrm{Ku}$ charz, złodziej, jego żona i jej kochanek (Francja-Holandia-Wlk. Brytania 1989) byl swego rodzaju wyznaniem wiary filmowca w teatr. W długich jazdach kamery tematyzował Greenaway iluzję czwartej ściany $\mathrm{w}$ pudełkowym mise en scène mimo wszystko filmowej czasoprzestrzeni, problematyzując związki postaci ze sceną za pomocą narracji kamery.

Przestrzeń kadru filmowego przestaje jednak Greenawayowi wystarczać. W roku 1994 wychodzi więc ze swymi pomysłami na ulice i place Genewy, by przemienić je w tworzywo scenicznego spektaklu patrzenia - pomiędzy ekspozycją, instalacją a happeningiem. A w rok później, w stulecie kina dokonuje - w sensie dosłownym - swoistej ekranizacji przestrzeni Monachium, tworząc monumentalną instalację światłocieniową na temat ekranów. I jeśli ów pierwszy spektakl udokumentuje w filmie Stairs 1 Geneva (Schody 1 Genewa, Szwajcaria 1995) - swego rodzaju instalacji filmowej - to drugi zyska swą notację w postaci dwutomowego albumu. Dwa media: kino i książka staną się archiwum pamięci przedsięwzięć parateatralnych, czymś więcej aniżeli tylko aneksem do tych wydarzeń [por. Kita 2003].

Ale znaczenie Schodów $1 .$. jest w istocie do uchwycenia jedynie $\mathrm{w}$ filmie. W tym sensie zdarzenie Greenawaya awansuje $\mathrm{w}$ istocie do 
rangi przedsięwzięcia multimedialnego. Genewa jako uliczny teatr spojrzeń i punktów widzenia daje pożywkę przedsięwzięciu nieledwie epistemologicznemu: filmowemu dyskursowi na temat miasta jako sceny, na którą kierowane są spojrzenia widzów. Bruk Genewy, oznaczający świat - chciałoby się rzec - i kino czerpiące $\mathrm{z}$ tego bruku pomysł na wyliczankę stu sites - widoków. Tutaj - jak w żadnym innym bodaj przypad$\mathrm{ku}$ - działanie sceniczne sprzęgnięte zostaje w jedno $\mathrm{z}$ notacją audiowizualną, tzn. ów teatr miasta staje się właściwym i jedynym tematem filmu. A czyż w poetyce wyliczanki, tak często kolportowanej w dziełach brytyjskiego filmowca, nie jest zawarta chociażby idea teatralnych didaskaliów?

A pamiętajmy, że jest to w gruncie rzeczy teatr bez aktorów, z udziałem raczej przypadkowych aktantów, którzy kierowani są ideologią widzialności właściwą kinu: stają się oni wojerami podglądającymi i współtworzącymi miejski environment. Ale to wojerystyczny film z kolei czyni $\mathrm{z}$ nich podmioty widowiska parateatralnego - swego rodzaju żywego planu teatru-filmu, filmu o teatrze i teatru dla filmu. Bo teatr miasta przenosi ich z teatru ulicy do świata filmowego, który nie jest ani filmem, ani teatrem, albo jest jednym i drugim jednocześnie - hybrydą na styku maszyny teatru i maszyny kina.

Taki właśnie jest sens tego filmu, będącego swoistą powtórką genewskiego spektaklu patrzenia i widzenia - kina $z$ ekspozycji, skrzętnie odliczanego miarą stu stron. Ale jak to zwykle u Greenawaya z późnego okresu twórczości bywa, na rzecz kinofikacji sceny świata pracują nieustannie nowe media. Nie tyle nawet jako nowy zestaw warsztatowy, ile przede wszystkim dyspozytyw postrzeżeniowy. Greenaway zastępuje bowiem strategię aranżowania prefilmowej mise en scène procesem designowania obrazu, inscenizowania jego obecności w niematerialnej powłoce kinematograficznej ikoniki. Tak się dzieje w Księgach Prospera i w filmie The Pillow Book (Francja-Wlk. Brytania-Holandia 1996), zwłaszcza zaś w „telewizyjnych” filmach-spektaklach A TV Dante i $M$ jak Mozart.

Być może eksperyment Greenawaya uczy też tego, jak rozstrzygać odwieczne dylematy dokumentacji spektakli teatralnych: przez tworzenie spektaklu widzenia w spektaklu pokazywania, tak jednak, by widz traktowany był jako obserwowany obserwator.

Ale przystępując do pracy nad Schodami, Greenaway miał przecież za sobą doświadczenie teatru w filmie. W Dzieciq̨tku $z$ Mâcon, a wcześniej już w filmie $M$ jak Mozart czy w Księgach Prospera, zwizualizował scenę jako teatr dla filmu, dając pojęciu ekranizacji zupełnie nowy sens: filmowego teatru, tzn. gry ulokowanej na styku przestrzeni scenicznej i filmowej, swego rodzaju wirtualnego miejsca pomiędzy mediami, miej- 
sca-niemiejsca, którego usytuowanie nie może mieć nic wspólnego z fizycznością locum. Stanowi raczej przestrzeń mentalną, element porządku odbioru, zawieszonego w wirtualności - o paradoksie! - ekranowej sceny. Stąd tak istotna rola przypisywana widzom w obrazie: to właśnie publiczność staje się właściwym bohaterem kina-spektaklu, testem na granice przedstawienia i wytrzymałość sceny (także tej filmowej) jako miejsca totalnego happeningu.

Nie inaczej postąpi Greenaway w setną rocznicę narodzin kina, inscenizując na fasadach monachijskich domów kolejny spektakl z cyklu The Stages, tym razem poświęcony projekcjom świetlnym (The Stairs 2 : Projection). Jakby w porywie przywrócenia kinu jego istoty, w pasji odkrywania na nowo X muzy, angielski artysta robi w mieście teatr z liczb projektowanych na fasady monachijskich budowli, odliczając swoim zwyczajem sto liczb na stulecie kina. Wyprowadzając spektakl świetlny z zamkniętej przestrzeni sali kinowej w miejski plener, Greenaway hybrydyzuje kino i architekturę - sztukę czasu i przestrzeni - ze sztuką przestrzeni, designuje smugami światła miejskie ulice i place po to, by $w$ zmianach światła odkryć ponownie źródło powstania projekcyjnych obrazów. „W kinie panuje ruch jednokierunkowy - pisał w katalogu monachijskiego spektaklu - dlatego trzeba wymyślić kino od nowa, tym bardziej, że wszelkie pozostałe media zdają się ku niemu zmierzać. Ale takie kino, w którym także publiczność byłaby mobilna i które byłoby w stanie «skolonizować nowe terytorium estetyczne»". Może zatem właśnie od cienia na ścianie należałoby rozpocząć na nowo historię kina po kinie? Może - paradoksalnie - w pozbawieniu kina filmu (a filmu kina) tkwi szansa na jego odratowanie? I może w ogóle należałoby rozpocząć od zakwestionowania seansu i zastąpienia go całodobowym kinem w naturze, do jakiego przywoływał w roku 1937 Stefan Themerson: „Wielki Człowiek w Kabinie Projekcyjnej rzuca na kopulasty ekran wciąż te same światła. Tym "operatorem" jest "Tama-nui-ki-te-Rangi - wielki-Człowiek-w-Niebie»" [Themerson 2002, 3205, 204].

Taka „praca u podstaw" kina, ale na ekranach oznaczających świat, jest $w$ gruncie rzeczy zabiegiem odratowywania medium poprzez reinstalowanie go w przestrzeni quasi-teatralnej. Jest aktem zwracania kina scenie świata, ale zarazem włączania go na nowo, po „przepracowaniu”, sztuce ruchomego obrazu. Tutaj kino rodzi się na nowo $\mathrm{z}$ ducha instalacji, która odsłania w nim to, co nieustannie przykrywa instytucja kina: spektakl światła [por. Elsaesser 1998, 45-66].

Teatralność tych dzieł w połączeniu $\mathrm{z}$ ich nowomedialną osnową dają $\mathrm{w}$ rezultacie coś $\mathrm{w}$ rodzaju teatru powierzchni obrazowej, swoisty spektakl powłoki medium, wymagającego od widza nieustannego nawigowania po obrazowych terytoriach. Greenawayowski teatr obrazu wyznacza 
pewien tor spotkania kina i teatru wiodący ku intermedialności współczesnej kultury artystycznej. Jest miejscem ścierania się choreografa obrazów i filmowca zanurzonego w idei sceny-instalacji, a w konsekwencji designera pracującego na rzecz usieciowienia obrazów i mediów. Tym, co w owych strategiach designowania liczy się najbardziej, to fakt aktywizowania interfejsów pomiędzy różnymi kulturami i ideologiami widzialności - świata wirtualnej sceny na styku kina i nowych mediów. Na podobnych napięciach „pomiędzy” zbudowana jest intermedialna dramaturgia jego scenicznych inscenizacji operowych: autorskiego filmu-opery (i opery-filmu zarazem) Rosa, a Horse Drama (1994, Amsterdam) oraz Krzysztofa Kolumba Dariusa Milhauda (z librettem Paula Claudela) w berlińskiej Staatsoper Unter den Linden (1998), integrującej akcję sceniczną z projekcjami filmowymi, ekran ze sceną, światłocieniowe fantomy z żywymi ciałami, tworząc - zwłaszcza w drugiej inscenizacji - coś w rodzaju teatru projekcji świetlnych. Alternacja żywych cial i ich ekranowych wizerunków prowadzi do nieustannych gier tożsamości oraz zakłóceń $\mathrm{w}$ postrzeganiu płaszczyzn przedstawieniowych, niosąc ze sobą bogaty rejestr manewrów zwodzenia.

To tutaj najpóźniej teatr staje się elementem kultury filmowej, a film interweniuje w scenę, tworząc spektakle medialnych interfejsów.

\section{BIBLIOGRAFIA}

Arnheim R. (1961), Perspektywy telewizji, w: tegoż, Film jako sztuka, przeł. W. Wertenstein, Warszawa.

Brewster B., Jacobs L. (1997), Theatre to Cinema. Stage Pictorialism and the Early Feature Film, Oxford.

Carroll N. (1996), Defining the Moving Image, w: tegoz, Theorizing the Moving Image, Cambridge.

Chyla W. (1987), Spektakl filmowy: fenomen $w$ stadium rozpoznania, w: J. Trzynadlowski (red.), Estetyka i struktura dzieła filmowego, Wrocław (,Studia Filmoznawcze” VI).

Comołłi J.-L. (2001), Maszyny widzialnego, przel. A. Piskorz, A. Gwóźdź, w: A. Gwóźdź (red.), Widzieć - myśleć - być. Technologie mediów, przekł. zbiorowy, Kraków.

Cywjan J. (2001), Rentgen, chirurgia, mikroskop w semiotyce wczesnego kina (Próba postawienia zagadnienia), przeł. B. Żyłko, w: T. Szczepański, B. Żyłko (red.), Cudowny Kinemo. Rosyjska myśl filmowa, przekł. zbiorowy, Gdańsk.

Elsaesser T. (1998), Raum-Körper. Peter Greenaways Re-Installation des Kinos, in: J. Felix (Hrsg.), Unter die Haut. Signaturen des Selbst im Kino der Körper, St. Augustin.

Elsaesser T. (2002), Filmgeschichte und frühes Kino. Archäologie eines Medienwandels, München.

Garncarz J. (1998), Vom Varieté zum Kino. Ein Plädoyer für ein erweitertes Konzept der Intermedialität, in: J. Helbig (Hrsg.) (1998). 
Gunning T. (1990), The Cinema of Attraction: Early Film, Its Spectator and the Avant-Garde, in: T. Elsaesser, A. Barker (eds.), Early Cinema: Space - Frame - Narrative, London.

Gwóźdź A. (2003), Obrazy i rzeczy. Film między mediami, Kraków (wyd. 2 przejrzane i poprawione),

Heider F. (1926), Ding und Medium, „Symposion“, H. 2.

Helbig J. (Hrsg.) (1998), Intermedialität. Theorie und Praxis eines interdisziplinären Forschungsgebiets, Berlin.

Hickethier K. (1996), Am Anfang der Elektrifizierung der Kultur - die ersten Filme und die Idee des Fernsehens, in: H. Segeberg (Hrsg.), Die Mobilisierung des Sehens. Zur Vor- und Frühgeschichte des Films in Literatur und Kunst, München.

Hoormann A. (2003), Lichtspiele. Zur Medienreflexion der Avantgarde in der Weimarer Republik, München.

Ingarden R. (1972), Kilka uwag o sztuce filmowej, w: A. Helman (red.), Estetyka i film, Warszawa.

Jay M. (1999), Nowoczesne wladze wzroku, przeł. M. Kwiek, w: E. Rewers (red.), Przestrzeń, filozofia $i$ architektura. Osiem rozmów o poznawaniu, produkowaniu $i$ konsumowaniu przestrzeni, Poznań.

Kita B. (2003), Między przestrzeniami. O kulturze nowych mediów, Kraków.

Luhmann N. (1986), Das Medium der Kunst, „Delfin“ VII.

Luhmann N. (1997), Medium und Form, w: tegoż, Die Kunst der Gesellschaft, Frankfurt/M.

McLuhan M. (1975), Wybór pism. Przekaźniki, czyli przedlużenie czlowieka. Galaktyka Gutenberga. Poza punktem zbiegu, wyboru dokonał J. Fuksiewicz, przel. oryginału angielskiego K. Jakubowicz, wstępem opatrzył K. T. Toeplitz, Warszawa.

Musser Ch. (1984), Toward a History of Screen Practice, „Quarterly Review of Film Studies" 9, Nr. 1 (Winter).

Paech J. (1997) Paradoxien der Auflösung und Intermedialität, w: M. Warnke, W. Coy, G. Ch. Tholen (Hrsg.), HyperKult. Geschichte, Theorie und Kontext digitaler Medien, Frankfurt/M.-Basel.

Paech J. (1998) Intermedialität. Mediales Differenzial und transformative Figuration, w: J. Helbig (Hrsg.) (1998).

Themerson S. (2002), O potrzebie tworzenia widzeń, w: A. Gwóźdź (red.), Europejskie manifesty kina. Od Matuszewskiego do Dogmy. Antologia, Warszawa.

Virilio P. (1984), Guerre et cinema I. Logistique de la perception, Paris.

Wollen P. (1982), „Ontology" and „Materialism" in Film, w: tegoż, Readings and Writings. Semiotic Counter-Strategies, London.

Zielinski S. (1989), Audiovisionen. Kino und Fernsehen als Zwischenspiele in der Geschichte, Reinbek bei Hamburg. 